\title{
Can Corporate Sustainability Influence Employee Engagement?
}

\author{
Georgia Simon (Corresponding author) \\ School of Management, Huazhong University of Science and Technology \\ Wuhan, China \\ Erhua Zhou (Iris) \\ School of Management, Huazhong University of Science and Technology \\ Wuhan, China
}

Received: April 19, 2018 Accepted: May 7, 2018 Online published: May 8, 2018

doi:10.5296/ijhrs.v8i2.13111 URL: https://doi.org/10.5296/ijhrs.v8i2.13111

\begin{abstract}
The global financial meltdown of 2008 has left many developing countries still trying to rebuild their economies and their labour forces. The aftermaths of the recession have inspired more businesses to incorporate sustainability into their business strategies. The sluggish growth, low productivity and other social, environmental and organizational factors have had an effect on the workforce. The unprecedented effects and outcome of disengagement worldwide have called leaders to find various initiatives to improve employee engagement. Rabid competition, coupled with the global figures of employee engagement has continued to attract both scholars and industry. The arguments put forward in this conceptual paper is meant to generate awareness as well as inspire further research into understanding how corporate sustainability might influence engagement of employees.
\end{abstract}

Keywords: corporate sustainability, employee engagement, strategic human resource management

\section{Introduction}

In a rabidly competitive global environment, accomplishing competitive advantage through an engaged workforce is the desire of organizational leaders. Employee Engagement (EE) has been found to have significance to employee and business level outcomes (Harter, Schmidt, $\&$ Hayes, 2002). The outcome of EE is valuable to organizations because of its value to bottom line outcomes (Harter et al, 2002). Consequently, EE is among the most researched 
organizational concepts of the last three decades, and have continued to attract interest theoretically and empirically among scholars and industry practitioners (Biro, 2013; Saks \& Gruman, 2014).

The focus of many of these studies have been influenced by the positive research outcomes and can be traced back to the early work of William Kahn in 1990, where he developed his engagement framework from examining the personal engagement levels of summer camp workers. Employee Engagement as defined by Kahn, is described as "the harnessing of organization member selves to their work roles; in engagement people employ and express themselves physically, cognitively, and emotionally during role performances" (Kahn, 1990). In fact, Kahn's work is widely known and accepted as the pioneering foundation of theorizing and subsequently defining the employee engagement construct.

Importantly, various scholars have since advanced the work of Kahn (Bakker \& Demerouti, 2008; Maslach \& Leiter, 2001; May et al., 2004; Saks, 2006; Schaufeli et al., 2008), among which many have even challenged his findings to extend their own theorization (Bakker \& Demerouti, 2007; Maslach et al., 2001; Schaufeli et al., 2008). Since then, various definitions, conceptualizations and measure have been forwarded in understanding the mechanisms that influence an employee to employ their discretionary effort to engage. Additionally, past proponents have found drivers and consequences of EE (Saks, 2006; Wollard \& Shuck, 2011). However, to date the construct still suffers from construct ambiguity, especially due to its conceptualization and measure, between academia and the practitioner domain. Consequently, this has contributed to the current diffusion, where other researchers have now argued that EE is a passing fad (Wollard \& Shuck, 2011), elusive construct (Saks, 2006) and a concept that should be ignored (Purcell, 2014).

Nonetheless, despite these assertions, due to the positive organizational outcome and the employee bahaviours that produce engagement, EE remains a construct worthy of further elucidation. In fact, it has been found that due to the dynamic nature of EE, drivers of EE are constantly changing. Therefore what will engage an employee may change tomorrow (Simon $\&$ Zhou, 2017). Accordingly, this has led some researchers to conceptualize EE as a multi-dimensional construct (Crawford, 2014; Saks, 2006). Furthermore, the argument on the multi-dimensionality and the current diffusion has influenced recent research to recommend future researchers to investigate EE with other organizational constructs (Saks \& Gruman, 2014).

\subsection{Importance of Sustainability}

The concept of sustainability has emerged as one of the most talked about research topics for this decade. Its far reaching impact and relevance have made sustainability a multi-discipline and multi-dimensional concept which has attained diverse meanings and interpretations over the past 30 years since its introduction in the Brundtland Report (1987). Corporate Sustainability (CS) is often used interchangeably with corporate social responsibility (CSR) which is defined as "context-specific organizational actions and policies that take into account stakeholders' expectations and the triple bottom line of economic, social, and environmental performance" (Aguinis, 2011). However, corporate sustainability is described 
as "a company that seeks to create long-term value to stakeholders by embracing the opportunities and managing risks that result from balancing economic, environmental, and social responsibility (Lazlo \& Zhexembayeva, 2011). Arguably, most organizations are highly driven by social and ethical responsibilities, and as such majority of the studies on CS examined its macro impact on the organization (Aguinis \& Glavas, 2012).

In fact, most studies have examined corporate sustainability as either the independent or dependent variable and at different levels of analysis (Aguinis \& Glavas, 2012; D'Aprile \& Talo, 2015; Jones, Selby, \& Sterling, 2010; Kolodinsky, Madden, Zisk, \& Henkel, 2010). In fact, quite a number of past researches on the construct have focused mainly on the environmental dimensions of the construct, with less on the organizational business aspect. This has led to the diffusion of its conceptualization in organizational studies and a failure to embody the holistic aspect of sustainability (Glavas \& Piderit, 2009; Sharpely, 2000). Though quite distinct from CSR, CS embodies similar characteristics as those in CSR, specifically concerning the social, environmental and economic factors.

Furthermore, due to an organizational role in a society's socio-economic development, the impact of CS can have far-reaching impact on competitive advantage and other socio-economical outcomes (Renwick, Redman, \& Maguire, 2012). Furthermore, organizations such as banks and other corporate entities are particularly interested in the aspect of shareholder value and competitive advantage (Lo \& Sheu, 2010). Moreover, more and more studies have alluded to the fact that there might be more to the concept, and that employees perception of CS in the organization could in fact influence their extra role behaviour (Farooq et al, 2016), job satisfaction (Dhonesh, 2014), well-being and feeling of meaningfulness (Glavas, 2014) or their engagement (Glavas \& Piderit, 2009) among other attitudinal and behavioural outcomes. Arguably, since studies on the specific impact of CS of employee engagement are unclear (Glavas \& Piderit, 2009), and further challenging due to its multi-discipline application (Bansal \& Song, 2017). Accordingly, it has been theorized that the aspects of CS such as the social, environmental, and economic factors could be the driver influencing an employee's discretionary behaviour (Belschak et al., 2015). Similar studies have highlighted the impact of CSR and sustainability factors on job satisfaction (Glavas \& Kelley, 2014), meaningfulness (Rosso, Dekas, \& Wrzesniewski, 2010), and organization citizenship behaviour (Lee \& Kim, 2015; Rupp, Shao, Thornton, \& Skarlicki, 2013).Furthermore, increasing studies are being undertaken by various discipline to increase the academic as well as organizational scope (Morgeson, Aguinis, Waldman, \& Siegel, 2013). Additionally, past studies have identified several antecedents and drivers of employee engagement (Saks, 2006; Shuck, 2011), and many other drivers of the concept are still unknown. Accordingly, this presents a gap on the specific mechanism at play in the CS and EE relationship (Glavas, 2012), and as such this study will contribute to expanding knowledge in the sustainability and engagement literature.

\subsection{Employee Engagement as a Business Imperative}

Employee engagement has emerged a significant factor in business sustainability for the last two decades. The outcome of EE have attracted organizational leaders, and have become a 
major business imperative. Recent studies have asserted that employees are seeking to find meaning and fulfillment at work, and as such employees of organizations that engage in sustainability or corporate social responsibility initiative have shown significance to the behaviour, and may contribute to employee engagement (Glavas, 2011). Even though it has been cited that only a few studies have considered EE as an outcome of CSR (Albdour \& Altarawneh, 2012), others have pointed to the relatedness of the construct on employee behaviour and EE (D’Aprile \& Talo, 2015; Rupp et al., 2013). In fact, most of the previous studies concentrated on the construct as either the predictor or outcome variable, and at the macro level of analysis (Aguinis \& Glavas, 2012; Jones et al., 2010). This has made way for further enquiry at the micro level of analysis, and from the perspective of the employees. Furthermore, studies that have investigated the effects of sustainability on employee behaviour have found that sustainability have contributed to various behavioural outcome such as organizational citizenship behaviour (OCB), job satisfaction and other factors similar to the drivers of EE (Caligiuri, Mencin, \& Jiang, 2013; Podsakoff, McKenzie, Lee, \& Podsakoff, 2009; Rupp \& Mallory, 2015). In fact, the arguments put forward in this review are influenced by past studies and premised on the findings which have demonstrated the various impact of CS on employees' behaviour and the employees' perception of its relatedness to their engagement. Furthermore, past proponents have argued that organizations should consider incorporating sustainability to other aspects of the organization, as past studies have focused mostly on the organization rather than the individuals (Aguinis \& Glavas, 2012; Carvalho \& Rabechini Junior, 2011). The study supports this assertion, and proposes that CS be incorporated as a strategic business imperative (Garcia-Castro et al., 2010; Pojasek, 2007).Arguably, the dynamism involved in engaging employees require constant innovation and readjustments of previous ideologies. In fact, the number of studies on the drivers and outcome of EE are many (Macey \& Schneider, 2008; Saks, 2006; Wollard $\&$ Shuck, 2011). However, the changing pace of the global workforce, and its subsequent impact of human behaviour have influenced the shifting of the metaphoric goal post of employee engagement, and employee engagement may fluctuate(Bakker, 2014), as EE is not consistent and the influencers means different things to different people (Simon \& Zhou, 2017) . Nonetheless, corporate sustainability may provide another level of explanation on the other factors influencing EE which may contribute significantly to the broader knowledge on the concept as well as to an organization's competitive advantage.

\section{The Corporate Sustainability and Employee Engagement Relationship}

\subsection{Influence on Corporate Sustainability on Employee Engagement}

As noted by past research, many of the studies on CS had to do with the financial outcomes of CS on the organization (Lo \& Sheu, 2010). Since corporate sustainability is similar to corporate social responsibility, certain aspects of the concept have theoretical overlap and present diffusion in conceptualization. However, CS is conceptually different from corporate social responsibility (Smith, 2011). Notwithstanding, the diffusion the outcome of both concept has great significance to business outcomes (Lazlo \& Zhexembayeva, 2011). Due to the multi-dimensional aspect of the construct, it is often challenged by a theoretical basis (Bansal \& Song, 2017). However, most past research has used the social identity theory 
(Hogg \& Terry, 2000; Hogg, 2016) as the theoretical framework for sustainability (Bramer et al., 2007). They opine that employee's moral identity (Rupp et al., 2013) and desire to find meaningfulness in their work (Rosso et al., 2010) may contribute to their engagement (Aguinis \& Glavas, 2013; Glavas \& Piderit, 2009). Social identity theory implies that the more an employee perceive their organization to be involved in sustainability, the more likely they will feel a positive attitude towards the organization which may influence their behaviour (Jones et al., 2010; Rupp et al., 2013).Furthermore, it was found that employees' attribute different motives of their organization's sustainability efforts and these motives influence employee performance (Story \& Neves, 2017) e.g. When employees perceive that their organization investment in a sustainability initiative or practices that are both intrinsic and extrinsic, they too will be prone to employing their discretionary effort to their work.

\subsection{Gap in Research Pertaining to Corporate Sustainability Effect on Employee Engagement}

A study done by Glavas (2016) highlighted that a gap exists in the understanding of how corporate sustainability (CS) impacts employee engagement (EE). To date other studies have contributed various theories and proposed conclusions about the relationship (Glavas \& Piderit, 2009; Morgeson et al., 2013; Rupp, 2013). However, there is a significant dissonance in the understanding of the specific mechanisms in the construct which influences employees' behaviour (Glavas \& Piderit, 2009; Rupp \& Mallory, 2015).In light of this , past proponent have alluded to the moral nature of the construct, and opine that people feel a moral pride, and sense of meaning to their job and organization when involved in sustainability practices (Glavas, 2014) .Furthermore, it was found that the perception of sustainability tend to trigger multiple behaviour in individuals. Similar studies have found significance between perceived CSR and employee identity (Jones, 2010), job satisfaction (Glavas \& Kelley, 2014), meaningfulness (Rosso et al., 2010) and organizational citizen behaviour (Lee \& Kim, 2015). Additionally, it has been opined that employees' positive behaviour is increased as a result of their identification of their organization's corporate social responsibility (Farooq et al., 2017; Shen \& Benson, 2016).

\section{Practical and Theoretical Implications}

\subsection{Implications for Practice}

Understanding the role and impact of Engagement on the overall organizational success is required for business longevity. If corporate sustainability can be positively linked to employee engagement and other positive organizational outcomes, then it would be indicative of organizations to use it as a Strategic HRM tool for engagement.

Both corporate sustainability and employee engagement can contribute to profitability and increased shareholder value (Glavas \& Godwin, 2016; Lazlo \& Zhexembayeva, 2011). Hence, organizations should invest in more studies that will enhance their understanding of the concepts, so that they will have the right understanding and consequently know how to sustain engagement levels among employees. Additionally, given the worldwide focus and attention on sustainability, it is incumbent on leaders to facilitate and educate employees on the far reaching impact of sustainability beyond the business scope. Sustainability awareness 
and practice is the step in the right direction to ensuring a better world to live and work in, and organizations that are aware of this, are likely ahead of their competitors in attaining competitive advantage.

\subsection{Implications for Theory}

The argument put forward in this paper is significant to theory by providing an enhanced framework for the existing literature on these constructs. Understanding the relationship between CS and EE would add significant knowledge to academic and industry literature, and also provide greater elucidation on advancing the theory and addressing the existing gaps. Furthermore, future researchers may develop a framework for employee engagement etched in sustainability.

\section{Conclusion}

The changing goal post of employee engagement makes for interesting studies. The diversity in the current drivers and the changing nature of human being will continue to inspire further study on the factors influencing employee engagement. Furthermore, the recommendation by some authors to measuring EE against other organizational variables may just be the answer in elucidating the construct. There is no doubt of the impact of an engaged workforce. Studies have found extensive findings that confirm its impact on various organizational variables (Alfes, Shantz, Truss, \& Soane, 2013; Bakker \& Bal, 2010; Bal, 2015; Christian et al.,2011;2014; Salanova et al., 2011; Whittingham \& Galpin, 2010) and most significantly is its impact on business outcome. Accordingly, the link between sustainability and employee engagement will no doubt have a profound impact on an overall sustainable business.

\section{References}

Aguinis, H. (2011). Organizational responsibility: Doing good and doing well. In S. Zedeck (Ed.),. In S. Zedeck (Ed.), APA handbook of industrial and organizational psychology. Washington, DC: American Psychological Association.

Aguinis, H., \& Glavas, A. (2012). What we know and what we don't know about corporate social responsibility: A review of research agenda. Journal of Management, 38(4), 932-968. https://doi.org/10.1177/0149206311436079

Alfes, K., Shantz, A. D., Truss, C., \& Soane, E. (2013). The link between perceived human resource management practices, engagement and employee behaviour: a moderated mediation model. International Journal of Human Resource Management, 24(2), 330-351. https://doi.org/10.1080/09585192.2012.679950

Bakker, A. B. (2014). Daily fluctuations in work engagement. European Psychologist, 19(4), 227-236. https://doi.org/10.1027/1016-9040/a000160

Bakker, A. B., \& Bal, P. M. (2010). Weekly work engagement and performance: A study among starting teachers. Journal of Occupational and Organizational Psychology, 83, 189-206. https://doi.org/10.1348/096317909X402596 
Bakker, A. B., Schaufeli, W. B., Leiter, M. P., \& Taris, T. W. (2008). Work engagement: An emerging concept in occupational health psychology. Work \& Stress, 22, 187-200. https://doi.org/10.1080/02678370802393649

Belschak, F. D., Den Hartog, D. N., \& Kalshoven, K. (2015). Leading Machiavellians: How to translate Machiavellians' selfishness into pro-organizational behavior. Journal of Management, 41, 1934-1956. https://doi.org/10.1177/0149206313484513

Biro, M. M. (2013). Employee engagement: Every leader's imperative. Retrieved January 29, 2018, from https://www.forbes.com/sites/meghanbiro/2013/05/19/employee-engagement-every-leaders-i mperative/

Caligiuri, P., Mencin, A., \& Jiang, K. (2013). Win-win-win: the influence of company-sponsored volunteerism programs on employees, NGOs, and business units. Personnel Psychology, 66, 825-860. https://doi.org/10.1111/peps.12019

Christian, M. S., Garza, A. S., \& Slaughter, J. E. (2011). Work engagement: A quantitative review and test of its relations with task and contextual performance. Personnel Psychology, 64(1), 89-136. https://doi.org/10.1111/j.1744-6570.2010.01203.x

Crawford, E. R., Rich, B. L., Buckman, B., \& Bergeron, J. (2014). The antecedent and drivers of employee engagement. In C. Truss, K. Alfes, \& R. Delbridge (Eds.), Employee Engagement in Theory and Practice (pp. 57-81). London: Rouledge.

D'Aprile, G., \& Talo, C. (2015). Analysis of community empowerment on projects sustainability: Moderating role of sense of community. Journal of Science Education \& Technology, 24(5), 671-683.

Dunphy, D., Griffiths, A., \& Benn, S. (2014). Organizational Change for Corporate Sustainability: A guide for leaders and change agents of the future. London,UK: Routledge.

Farooq, O., Rupp, D. E., \& Farooq, M. (2016). The multiple pathways through which internal and external corporate social responsibility influence organizational identification and multifoci outcomes: The moderating role of cultural and social orientations. Academy of Management Journal, 60, 954-985. https://doi.org/10.5465/amj.2014.0849

Glavas, A. (2012). Employee engagement and sustainability: A model for implementing meaningfulness at and in work. Journal of Corporate Citizenship, 2012(46), 13-29. https://doi.org/10.9774/GLEAF.4700.2012.su.00003

Glavas, A. (2016). Corporate social responsibility and employee engagement: Enabling employees to employ more of their whole selves at work. Frontier in Psychology, 7(796), 1-10. https://doi.org/10.3389/fpsyg.2016.00796

Glavas, A., \& Kelley, K. (2014). The effects o perceived corporate social responsibility on employees. Business Ethics Quarterly, 24, 165-202. https://doi.org/10.5840/beq20143206 


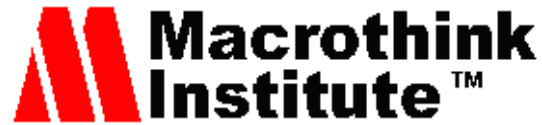

International Journal of Human Resource Studies ISSN 2162-3058

Glavas, A., \& Piderit, S. K. (2009). How Does Doing Good Matter? Effects of Corporate Citizenship on Employees. Journal of Corporate Citizenship, 36, 51-70. https://doi.org/10.9774/GLEAF.4700.2009.wi.00007

Harter, J. K., Schmidt, F. L., \& Hayes, T. L. (2002). Business-unit level relationship between employee satisfaction, employee engagement, and business outcomes: A meta-analysis. Journal of Applied Psychology, 87(2), 268-279. https://doi.org/10.1037/0021-9010.87.2.268

Hogg, M. A., \& Terry, D. J. (2001). Social Identity Processes in Organizational Contexts. Psychology Press.

Hogg, M. A., Abrams, D., Otten, S., \& Hinkle, S. (2004). The social identity perspective: Intergroup relations, self-conception, and small groups. Small Group Resource, 35, 246-276. https://doi.org/10.1177/1046496404263424

Jones, D. A. (2010). Does serving the community also serve the company? Using organizational identification and social exchange theories to understand employee responses to a volunteerism program. Journal of Occupational and Organizational Psychology, 83(4), 857-878. https://doi.org/10.1348/096317909X477495

Jones, P., Selby, D., \& Sterling, S. (2010). Sustainability education: Perspectives and practice across higher education. London, UK: Earthscan.

Kahn, W. A. (1990). Psychological conditions of personal engagement and disengagement at work. Academy of Management Journal, 33(4), 692-724. https://doi.org/10.2307/256287

Kolodinsky, R. W., Madden, T. M., Zisk, D. S., \& Henkel, E. T. (2010). Attitudes about corporate social responsibility: Business student predictors. Journal of Business Ethics, 91, 167-181. https://doi.org/10.1007/s10551-009-0075-3

Laszlo, C., \& Zhexembayeva, N. (2011). Embedded sustainability: The next big competitive advantage. Palo Alto,CA: Stanford University Press.

Lee, M., \& Kim, W. (2015). The effect of perceived corporate social responsibility on hotel employees' attitude and behaviour toward the organization. International Journal of Tourism Science, 13, 51-74. https://doi.org/10.1080/15980634.2013.11434680

Lo, S., \& Sheu, H. (2010). Does corporate sustainability matter to investors? African Journal of Business Management, 4(13), 2856-2863.

Maslach, C., Schaufeli, W. B., \& Leiter, M. P. (2001). Job Burnout. Annual Review of Psychology, 52, 397-422. https://doi.org/10.1146/annurev.psych.52.1.397

May, D. R., Gilson, L., \& Harter, L. (2004). The psychological conditions of meaningfulness, safety and availability and the engagement of the human spirit at work. Journal of Occupational and Organizational Psychology, 77, 11-37. https://doi.org/10.1348/096317904322915892 
Podsakoff, P. M., McKenzie, S. B., Lee, J. Y., \& Podsakoff, N. P. (2003). Common method bias in behavioural research: A critical review of literature and recommended remedies. Journal of Applied Psychology, 88(5), 879-903. https://doi.org/10.1037/0021-9010.88.5.879

Purcell, J. (2014). Disengaging from engagement. Human Resource Management Journal, 24(3), 241-254. https://doi.org/10.1111/1748-8583.12046

Renwick, D. W. S., Redman, T., \& Maguire, S. (2012). Green human resource management: A review and research agenda. International Journal of Management Reviews. https://doi.org/10.1111/j.1468-2370.2011.00328.x

Rosso, B. D., Dekas, K. H., \& Wrzesniewski, A. (2010). On the meaning of work: A theoretical integration and review. Research in Organizational Behaviour, 30, 91-127. https://doi.org/10.1016/j.riob.2010.09.001

Rupp, D. E., \& Mallory, D. B. (2015). Corporate social responsibility: Psychological, person-centric, and progressing. Annual Review of Organizational Psychology and Organizational Behaviour, 2(1), 211-236. https://doi.org/10.1146/annurev-orgpsych-032414-111505

Rupp, D. E., Shao, R., Thornton, M. A., \& Skarlicki, D. P. (2013). Applicants' and employees' reactions to corporate social responsibility: The moderating effects of first-party justice perceptions and moral identity. Personnel Psychology, 66(4), 895-933. https://doi.org/10.1111/peps.12030

Saks, A. M. (2006). Antecedents and consequences of employee engagement. Journal of Managerial Psychology, 21(7), 600-619. https://doi.org/10.1108/02683940610690169

Saks, A. M., \& Gruman, J. A. (2014). What do we really know about employee engagement? Human Resource Development Quarterly, 25(2), 155-182. https://doi.org/10.1002/hrdq.21187

Schaufeli, W. B. (2014). What is engagement? In C. Truss, K. Alfes, R. Delbridge, A. Shantz, \& E. Soane (Eds.), Employee Engagement in Theory and Practice (pp. 15-35). Routledge.

Schaufeli, W. B., \& Bakker, A. B. (2004). Job demands, job resources, and their relationship with burnout and engagement: A multi-sample study. Journal of Organizational Behaviour, 25(3), 293-315. https://doi.org/10.1002/job.248

Schaufeli, W. B., \& Bakker, A. B. (2010). Defining and measuring work engagement: Bringing clarity to the concept. In A. B. Bakker \& M. P. Leiter (Eds.), Work engagement: A handbook of essential theory and research (pp. 10-24). New York, NY: Psychology Press.

Schaufeli, W. B., Salanova, M., Gonzalez, R. V., \& Bakker, A. B. (2002). The measurement of engagement and burnout: A two sample confirmatory factor analytic approach. Journal of Happiness Studies, 3(10), 71-92. https://doi.org/10.1023/A:1015630930326

Schaufeli, W. B., Taris, T. W., \& Van Rhenen, W. (2008). Workaholism, burnout, and work engagement: Three of a kind or three different kinds of employee well-being? Applied 


\section{Macrothink}

International Journal of Human Resource Studies

ISSN 2162-3058 2018, Vol. 8, No. 2

Psychology: An International Review, $\quad$ 57, 173-203. https://doi.org/10.1111/j.1464-0597.2007.00285.x

Sharpely, R. (2000). Tourism and sustainable development Exploring the theoretical divide. Journal of Sustainable Tourism, (8), 1-19. https://doi.org/10.1080/09669580008667346

Shen, J., \& Benson, J. (2014). When CSR is social norm: How socially responsible human resource management affects work behaviour. Journal of Management, 40, 1-24.

Shuck, B. (2011). Integrative literature review: four emerging perspectives of employee engagement: an integrative literature review. Human Resource Development Review, 10(3), 304-328. https://doi.org/10.1177/1534484311410840

Simon, G., \& Zhou, I. (2017). Harmonizing modern day employee engagement with the sociological theory of symbolic interactionism. American Journal of Business and Management, 6(2), 52-59.

Stairs, M. (2005). Work Happy: Developing employee engagement to deliver competitive advantage. Selection and Development Review, 21(5), 7.

Story, J., \& Neves, P. (2015). When corporate social responsibility increases performance: exploring the role of intrinsic and extrinsic CSR attribution. A European Review, 24(2), 111-124. https://doi.org/10.1111/beer.12084

Truss, C., Alfes, K., Shantz, A., \& Soane, E. (Eds.). (2014). Employee engagement in theory and practice. London: Routledge.

Wollard, K. K., \& Shuck, B. (2011). Antecedents to employee engagement: A structured review of the literature. Advances in Developing Human Resources, 13(4), 429-446. https://doi.org/10.1177/1523422311431220

\section{Copyright Disclaimer}

Copyright for this article is retained by the author(s), with first publication rights granted to the journal.

This is an open-access article distributed under the terms and conditions of the Creative Commons Attribution license (http://creativecommons.org/licenses/by/4.0/). 